\title{
Olhares interiores
}

\author{
ENSAIO FOTOGRÁFICO
}

Pierre Devin ${ }^{1}$

A paixão militante é bela, desde que não submetida a nenhuma palavra de ordem, $e$ aureolada do espírito da liberdade, sempre que busca, por seu desejo de convencer, antes de mais nada, o desabrochar da liberdade de seus destinatários.

Tal é o papel exemplar do Centro Regional da Fotografia Nord Pas-de-Calais. Seus responsáveis são movidos por uma devorante paixão por sua região; eles conhecem tão bem os contornos atmosféricos gerais de seus arredores, quanto partilham das vicissitudes de seu povo, confrontado à crise industrial que assolou as comunidades operárias.

Uma igual paixão pela fotografia os conduziu a um largo gesto de liderança junto a

numerosos atores. 'Arquivos do Norte' não é mais apenas o título de um livro célebre, é um gesto cotidiano para o Centro Regional da Fotografia.

Que as criações em curso de grandes artistas contemporâneos neste domínio se apoiem, um tempo, sobre as perturbações de uma região para figurar a sua metamorfose.

Que a fotografia não renuncie em nada a suas prerrogativas de inventar um ponto de vista, que uma região nela encontre razão de se compreender e de se transformar, são fatos que mereciam homenagem; o humanismo jamais a recebe em demasia.

Bernard Lamarche-Vadel, outubro de 1991.

${ }^{1}$ diretor do Centro Regional de Fotografia, Nord Pas-de-Calais, França.

* Versão em português do original francês. 


\section{O Centro Regional da Fotografia (CRF)}

Poucas estruturas são dedicadas à fotografia na França. Apenas cinco centros de arte, entre os quais o Centro Regional da Fotografia, são reconhecidos pelo Ministério da Cultura. Certos museus começam a se interessar pelo patrimônio fotográfico e é com uma grande timidez que eles abordam episodicamente a fotografia contemporânea. De resto, o aparelho histórico e crítico concernente à fotografia é ainda bastante incompleto. Amostras inteiras de produção permanecem desconhecidas. No que concerne à criação fotográfica contemporânea, a pesquisa na França está nos seus primórdios.

\section{A fotografia em debate}

O debate se desenvolve em torno da própria matéria da fotografia - que, desde sua origem, coloca questões artísticas -, da especificidade do meio e das interações entre ética e estética que se dão na imagem, onipresente em nosso mundo.

No período contemporâneo, a fotografia está, como todas as artes, na origem de múltiplos questionamentos. A esse debate acrescentam-se questões específicas ao meio e à sua história, que dizem respeito à sua bastardia, à sua indexação ao real, aos modos de produção e, enfim, à introdução da imaginária numérica.

Desde sempre, por causa de seu recurso à tecnologia e da multiplicidade de seus usos, da qual decorre sua bastardia, a fotografia é posta em dúvida quanto a sua capacidade de ser um meio artístico. Questões epistemológicas lhe são opostas, sem cessar. Seria uma "arte média", uma "disciplina sem disciplina", pela qual amadores e praticantes de um uso utilitário da fotografia revelaram-se artistas.

"Desperdiçou-se tempo em vãs sutilezas a fim de se decidir se a fotografia deveria ser ou não uma arte, mas não se indagou, antes, se esta mesma invenção não transformaria o caráter geral da arte" (Walter Benjamin).

\section{Papel cultural}

O CRF desempenhou e desempenha um papel na cidade, pela mediação $e$ reflexão que conduz a respeito de novas questões para a cidadania. Ele toma partido na reflexão sobre as relações entre a imagem e o visível e os questionamentos desta região (Nord Pas-de-Calais) quanto a sua identidade, seu futuro e sua representação.

O CRF reivindica seu papel como um ator da evolução cultural e, neste sentido, trabalha sobre as necessárias interações com o conjunto do tecido vivo. Desde a origem, o alargamento da oferta cultural e o alargamento dos públicos, numa região onde por muito tempo a segregação cultural foi um 
dos aspectos da segregação social, é para ele um compromisso maior.

Concretamente, o CRF vinculou-se a uma política inovadora em matéria de formação. Bem antes das recomendações, em 1986, do Ministério da Educação Nacional sobre a necessidade da leitura e da crítica da imagem, ele conduziu experiências pedagógicas que integravam a fotografia.

Correlativamente, o Centro se dedicou à necessária formação inicial ou contínua dos mestres. Esta démarche foi confirmada por ações em direção aos públicos ditos difíceis (públicos em fracasso escolar, pré-delinqüentes, prisioneiros...), em que a fotografia se revelou, além de uma necessária aprendizagem da leitura e da crítica da imagem, uma possibilidade de descoberta do mundo, de expressão e, portanto, de remotivação. Neste quadro, o CRF sempre propôs encontros fortes com obras fortes. Elas funcionam sobre o inteligível e o sensível para produzir sentido. O sensível, tão desvalorizado na escola francesa, encontra-se, portanto, revalorizado junto àqueles que sofreram o fracasso escolar por causa de uma preponderância do inteligível, para o qual eles não estavam prontos. Para além do encontro da obra, que parecia pertencer a um mundo inacessível, trata-se também de uma reconciliação consigo mesmo, sua identidade e de uma remotivação para a descoberta. "Os povos declinam a partir do momento em que eles perdem a vontade de reconquistar a cada geração sua identidade cultural sempre minada pelo movimento da história" (Claude Montassier). Freqüentemente, esses processos incluem, em algum momento, o encontro com o artista. Isto é para o artista uma experiência muito forte, e para o público, a tomada de consciência ou a confirmação de que o artista é um cidadão.

O acesso a este tipo de cultura é uma condição fundamental de justiça social e de desenvolvimento do espírito de criação. Não podemos, portanto, demandar à cultura resolver as conseqüências da crise, de ser um ungüento, um adjuvante.

Ao contrário, a ação cultural fundada em conteúdos fortes deve culminar numa apropriação ativa. Na sua prática, o CRF demonstrou que, em relação à imagem, era possível: escapar à fascinação da sua mobilidade, inverter os hábitos de consumo, achar o prazer de encontrar artistas e obras fortes $e$ experimentar o desejo de expressão pela fotografia.

Estas práticas são possíveis porque a tecnologia permanece artesanal $e$, portanto, mesmo uma criança pequena pode seguir o processo do enquadramento à tiragem, à seleção, à montagem final, porque ela é fixa $e$ a reflexão sobre o quadro representa uma passagem obrigatória de toda formação inicial, profissional ou contínua da imagem. As motivações são tanto maiores quanto mais se descobre a polissemia das imagens, mais se pode jogar com todas as suas variáveis, mais esse jogo se torna um espaço de liberdade. 


\section{Situação concreta}

Olhares interiores é um fato raríssimo. Trabalhadores, no caso empregados do Centro Hospitalar Universitário de Lille, tiveram vontade de fotografar seu local de trabalho. Ver, para fazer ver, é também conceber. Para isso, transgrediram diversas barreiras: a fotografia está mais associada a férias que a trabalho, o que exigiu explicar ao seu meio que se tratava de lazer - o tempo livre do estudo (do latim, otium); a arquitetura do hospital do início dos anos cinqüenta é considerada austera e desumana, e eles mostraram que ela poderia ser revivificada pelo imaginário. Também mostraram os bastidores do hospital, aquilo que o público não vê jamais e que, contudo, constitui sua vida cotidiana: salas de cirurgia, escritórios, lojas, lavanderia, caldeiraria, necrotério... Esta última imagem quase foi proibida pela direção, exigindo toda diplomacia dos mediadores para explicar que era um trabalho de expressão e não uma campanha de comunicação. Mas o ponto de maior resistência foi o de olhar de frente seu ofício, confrontado diariamente com a vida, a morte e o sofrimento.

A visão fotográfica que se desprende dessa experiência é plena de humanidade, sem ênfase, com a distância sensível. Foi por todas essas transgressões que o CRF apoiou o projeto.

Fotografias de:

Jacques Barraqué, Marcelline Bartos, Bruno Becquet, José Coenda, François Depienne, Stéphane Duquesnoy Jean-luc Faucompré, Jean-Marie Fourdrin, Maryse Hilton, Eric Lenouvel, Alain Vanderhaegen 